Research Paper

\title{
Gender-dimorphic effects of adipose-derived stromal vascular fractions on HUVECs exposed to oxidative stress
}

Soyeon Lim ${ }^{1,2, *}$, Il-Kwon Kim ${ }^{1,3,}{ }^{,}$, Jung-Won Choi ${ }^{1,2}$, Hyang-Hee Seo ${ }^{4}$, Kyu Hee Lim ${ }^{5}$, Seahyoung Lee ${ }^{1,2}$, Hoon-Bum Lee ${ }^{1,7}$, Sang Woo Kim ${ }^{1,2 \bowtie}$ and Ki-Chul Hwang ${ }^{1,2 \bowtie}$

1. Catholic Kwandong University, International St. Mary's Hospital, Incheon Metropolitan City, 22711, Republic of Korea

2. Institute for Bio-Medical Convergence, College of Medicine, Catholic Kwandong University, Gangneung-si, Gangwon-do 25601, Republic of Korea

3. Cell Therapy Center, Catholic Kwandong University International St. Mary's Hospital, Incheon Metropolitan City, 22711, Republic of Korea

4. Brain Korea 21 PLUS Project for Medical Science, Yonsei University College of Medicine, Seoul 03722, Republic of Korea

5. Department of Veterinary Physiology, College of Veterinary Medicine, Biosafety Research Institute, Chonbuk National University, Jeonju City, Jeollabuk-Do, Republic of Korea

6. Department of Integrated Omics for Biomedical Sciences, Graduate School, Yonsei University, Seoul, 03722, Republic of Korea

7. Department of Plastic and Reconstructive Surgery, Catholic Kwandong University, International St. Mary's Hospital, Incheon Metropolitan City, 22711, Republic of Korea

*S. Lim and I.-K. Kim contributed equally to this work.

$\square$ Corresponding author: Ki-Chul Hwang and Sang Woo Kim, Catholic Kwandong University, International St. Mary's Hospital, Incheon Metropolitan City, 404-834, Republic of Korea. Tel: +82-32-290-3883, Fax: +82-32-290-2774, E-mail: kchwang@cku.ac.kr (K.-C. Hwang). Tel: +82-32-290-2612, Fax: +82-32-290-2774, E-mail: ksw74@cku.ac.kr (S.W. Kim)

(C) Ivyspring International Publisher. This is an open access article distributed under the terms of the Creative Commons Attribution (CC BY-NC) license (https://creativecommons.org/licenses/by-nc/4.0/). See http://ivyspring.com/terms for full terms and conditions.

Received: 2017.03.09; Accepted: 2017.05.17; Published: 2017.07.20

\begin{abstract}
Stromal vascular fractions (SVFs) are a heterogeneous collection of cells within adipose tissue that are being studied for various clinical indications. In this study, we aimed to determine whether SVF transplantation into impaired tissues has differential effects on inflammatory and angiogenetic properties with regard to gender. As reactive oxygen species have been implicated in cardiovascular disease development, we investigated differences in gene and protein expression related to inflammation and angiogenesis in HUVECs co-cultured with adipose-derived SVFs from male ( $M$ group) and female ( $F$ group) individuals under oxidative stress conditions. The expression of several inflammatory (interleukin (IL)-33) and angiogenetic (platelet-derived growth factor (PDGF)) factors differed dramatically between male and female donors. Anti-inflammatory and pro-angiogenetic responses were observed in HUVECs co-cultured with SVFs under oxidative stress conditions, and these characteristics may exhibit partially differential effects according to gender. Using network analysis, we showed that co-culturing HUVECs with SVFs ameliorated pyroptosis/apoptosis via an increase in oxidative stress. Activation of caspase-1 and IL-1B was significantly altered in HUVECs co-cultured with SVFs from female donors. These findings regarding gender-dimorphic regulation of adipose-derived SVFs provide valuable information that can be used for evidence-based gender-specific clinical treatment of SVF transplantation for understanding of cardiovascular disease, allowing for the development of additional treatment.
\end{abstract}

Key words: Human adipose-derived stromal vascular fractions; Gender; HUVECs; Oxidative stress; Inflammation; Angiogenesis

\section{Introduction}

Stromal vascular fractions (SVFs) are a heterogeneous collection of cells within adipose tissue that contain adipose-derived stem cells (ASCs), endothelial (progenitor) cells, vascular smooth muscle cells, mesenchymal stem cells (MSCs), fibroblasts, macrophages, $\mathrm{T}$ regulatory cells and pericytes $[1,2]$. 
This complex, heterogeneous population has immense potential for therapeutic applications and is being studied for various clinical indications such as lipotransfer, diabetes-related complications, nerve regeneration, burn wounds and other uses [1, 2]. The potential for SVF transplantation as a therapy for heart disease is also being actively investigated [3-6]. In rodent and pig models of acute and chronic myocardial infarction, ASCs improved cardiac function and perfusion [3-5]. Moreover, Premaratne et al. claimed that SVF transplantation might be useful for therapeutic angiogenesis in chronic ischemic heart disease and may partly exert cardioprotective effects in chronic ischemic myocardium [6]. In fact, SVF transplantation inhibited the secretion of proinflammatory cytokines such as tumor necrosis factor alpha (TNF-a) and interleukin 6 (IL-6) in a cardiac disease model [6] and induced neovascular formation in ischemic muscle and myocardial infarction [6, 7]. Nevertheless, the recent status of clinical studies on SVF transplantation in various diseases has not been fully investigated $[8,9]$.

Produced by inflammatory processes, hydrogen peroxide induces oxidative stress that can contribute to endothelial dysfunction and cellular injury, which in turn contribute to atherosclerosis and other cardiovascular diseases $[10,11]$. Increases in reactive oxygen species (ROS) are related to the onset of cardiovascular diseases, including hypertension and atherosclerosis $[12,13]$. Overall, our understanding of the molecular control and of the developmental significance of trans-determination processes awaits further experimental evidence; nonetheless, the possibility of using stem/progenitor cells for tissuespecific cell therapy offers exciting perspectives for future clinical application. In this context, heart tissue is obviously a major target. Work by Condorelli and colleagues shows that human umbilical vein endothelial cells (HUVECs) trans-differentiate to a cardiomyocyte phenotype when co-cultured with rat cardiomyocytes [14]. Although the molecular mechanisms of trans-differentiation remain unknown, if substantiated and further optimized, conversion of endothelial cells into cardiomyocytes could have many therapeutic implications. Such studies suggest that environments within the developing heart may at least temporarily permit some precursor cells to follow either a cardiomyocyte or endothelial cell developmental programs. Accordingly, we aimed to determine whether SVF transplantation into impaired tissues has differential effects according to various conditions including aging or gender-dimorphic aspects.

The activity of transplanted stem cells can vary significantly by gender [15]. For example, MSCs from two-year-old female Rhesus monkeys showed greater neurogenic capacity than MSCs from male monkeys [16], and neural stem cells (NSCs) obtained from young and old rats exhibited sexual dimorphism in neural fate and steroid receptor levels [17]. Hematopoietic stem cells in mice presented gender differences in cell-cycle regulation in response to estrogen [18]. Additionally, cytokine expression by MSCs harvested from the bone marrow of male mice has been observed to have a higher concentration of IL-6 and TNF and a lower concentration of vascular endothelial growth factor (VEGF) than cells derived from female bone marrow [19]. Although the importance of gender as a key determinant in stem cell transplantation has been recognized for a long time, systematic studies on gender differences in an attempt to develop gender-specific treatment are still lacking. In particular, only a few studies have investigated gender differences in SVF transplantation in diseases $[9,15,18]$.

In this study, we aimed to determine whether SVF transplantation into impaired tissues shows differential effects according to gender in terms of inflammatory and angiogenetic properties. Therefore, we investigated the differences in gene and protein expression related to inflammation and angiogenesis in HUVECs co-cultured with adipose-derived SVFs from males (M group) and females (F group) under oxidative stress conditions because redox signaling influences many physiological processes in the heart and plays a critical role in pathological cardiac remodeling [20, 21]. Interestingly, dramatic differences were found in the expression of some inflammatory and angiogenetic factors between the male and female donors. In addition, Database for Annotation, Visualization, and Integrated Discovery (DAVID) network analysis suggested that in HUVECs co-cultured with SVFs, pyroptosis/apoptosis was ameliorated via an increase oxidative stress conditions. Specifically, caspase-1 (CASP1) and IL-1B levels were considerably altered in HUVECs co-cultured with SVFs from female donors. These findings on the gender-dimorphic regulation of adipose-derived SVFs provide valuable information that can be used for the evidence-based, genderspecific clinical application of SVF transplantation for cardiac diseases.

\section{Materials and Methods}

\section{Donors}

The 7 donors were recruited at the International St. Mary's Hospital of Catholic Kwandong University, and their fat was acquired from the abdominal wall by gentle manual techniques. The donors included three males and four females (Table 1), and one 
female sample was used for only characterization of SVFs (Fig. 1A). The study protocol was approved by the ethics review committee of the Institutional Review Board of the College of Medicine, Catholic Kwandong University.

Table 1. Information about the analyzed donors

\begin{tabular}{llll}
\hline Group & Number & Age (Year) & Purpose of treatment \\
\hline Male group (M) & $\# 1$ & 47 & Rejuvenation \\
& $\# 2$ & 42 & Rejuvenation \\
& $\# 3$ & 62 & Rejuvenation \\
Female group (F) & $\# 1$ & 45 & Depilation \\
& $\# 2$ & 62 & Arthritis \\
& $\# 3$ & 61 & Arthritis \\
Characterization (F) & $\# 1$ & 53 & Arthritis
\end{tabular}

\section{Culture of adipose-derived SVFs and HUVECs}

SVFs were isolated from human adipose tissue using the Smart X kit (Dongkoo bio \& pharma Co., Seoul, South Korea) according to the manufacturer's instructions. The SVFs were cultured in Dulbecco's Modified Eagle's Media (DMEM; HyClone) containing 10\% FBS (HyClone, Logan, UT, USA) and $1 \%$ penicillin/streptomycin at a density of $5 \times 10^{4}$ cells $/ \mathrm{cm}^{2}$ in $100 \mathrm{~mm}$ dish in a humidified atmosphere with $5 \% \mathrm{CO}_{2}$ at $37^{\circ} \mathrm{C}$ and were passaged 3 times. HUVECs (Lonza, Walkersville, MD, USA) were cultured in Clonetics ${ }^{\mathrm{TM}}$ Endothelial Growth Basal Medium 2 (EBM-2; Lonza) supplemented with Clonetics $^{\mathrm{TM}}$ Endothelial Growth Medium 2 (EGM-2) SingleQuots (Lonza) using plates coated with $0.1 \%$ gelatin (BD Biosciences, Sparks, MD, USA) in a humidified atmosphere of $5 \% \mathrm{CO}_{2}$ and $95 \%$ air at $37^{\circ} \mathrm{C}$.

\section{Cell viability assay}

The HUVECs were seeded $24 \mathrm{hrs}$ prior to $\mathrm{H}_{2} \mathrm{O}_{2}$ treatment at a density of $5 \times 10^{4}$ cells $/ \mathrm{cm}^{2}$ onto 96 -well plates and were treated with $\mathrm{H}_{2} \mathrm{O}_{2}(0-50 \mu \mathrm{M})$ for 2, 4, or $6 \mathrm{hrs}$. After the addition of $10 \mu \mathrm{L}$ of Ez-Cytox (Daeillab, Seoul, Korea) into each well, cell viability was evaluated by measuring the optical density at 450 nm.

\section{Reactive oxygen species (ROS) detection assay}

The HUVECs were plated $24 \mathrm{hrs}$ prior to $\mathrm{H}_{2} \mathrm{O}_{2}$ treatment at a density of $5 \times 10^{4}$ cells $/ \mathrm{cm}^{2}$ in 6-well plates, and ROS was induced after a 2, 4, or $6 \mathrm{hrs}$ treatment with 0-50 $\mu \mathrm{M} \mathrm{H}_{2} \mathrm{O}_{2}$, followed by exposure to $50 \mu \mathrm{M}$ DCF-DA (Sigma-Aldrich, St. Louis, MO, USA) for $30 \mathrm{~min}$ at $37^{\circ} \mathrm{C}$ in the dark. Green fluorescence was detected using a BD AccuriC6 Cytometer (BD Biosciences, Piscataway, NJ, USA).

\section{Co-culture of SVF and HUVECs}

HUVECs at passage 5 were plated $24 \mathrm{hrs}$ prior to
$\mathrm{H}_{2} \mathrm{O}_{2}$ treatment at a density of $5 \times 10^{4}$ cells $/ \mathrm{cm}^{2}$ in 6-well plates and were then treated with or without $\mathrm{H}_{2} \mathrm{O}_{2}$ at $40 \mu \mathrm{M}$ for $4 \mathrm{hrs}$. The cells were co-cultured with individual SVFs of passage 3 in trans-well inserts with a $0.4-\mu \mathrm{m}$ porous translucent PET membrane (FALCON, Pittston, PA, USA). After incubation for 24 and $48 \mathrm{hrs}$, cells in the lower well were harvested for further analysis. The experimental groups were designated as follows: group 1 (negative control; NC), HUVECs (monoculture); group $2\left(\mathrm{H}_{2} \mathrm{O}_{2}\right)$, HUVECs (monoculture) $+\mathrm{H}_{2} \mathrm{O}_{2}$; groups 3,4 , and $5(\mathrm{M})$, HUVECs and SVFs (males \#1, \#2, or \#3, co-culture) + $\mathrm{H}_{2} \mathrm{O}_{2}$; groups 6,7 , and $8(\mathrm{~F})$, HUVECs and SVFs (females \#1, \#2, or \#3, co-culture) $+\mathrm{H}_{2} \mathrm{O}_{2}$.

\section{Flow cytometry}

Flow cytometry was performed according to our previous work [22]. Cells were collected using Accutase Cell Detachment Solution (Thermo, Louisville, CO, USA), antibodies were purchased from Santa Cruz Biotechnology (Santa Cruz, CA, USA), and cells were analyzed using a BD AccuriC6 Cytometer.

\section{Immunoblot analysis}

Immunoblot analysis was performed according to our previous work [22]. Primary polyclonal antibodies and horseradish peroxidase-conjugated secondary antibody (Santa Cruz Biotechnology) were used for protein detection. Proteins were visualized using an enhanced chemiluminescence (ECL, Western Blotting Detection kit, GE Healthcare, Sweden) system, and the band intensities were quantified using ImageJ software.

\section{Quantitative real-time PCR (qPCR)}

Transcript levels were quantified using the Applied Biosystems StepOnePlus real-time RT-PCR System (Foster City, CA, USA). Total RNA was isolated from cells using TRIZOL Reagent Solution (Life Technologies, Frederick, Maryland, USA), and reverse-transcription was performed using a Maxime RT Premix kit (iNtRON Biotechnology, Seongnam, Korea). We employed the SYBR Green Dye system (Applied Biosystems) for real-time PCR. Sequences of primer sets are listed in Table 2.

\section{Network analysis}

The DAVID v6.8 database provides a comprehensive set of functional annotation tools to determine the biological relevance of many genes/ proteins [23]. DAVID provides the ability to visualize genes on BioCarta and KEGG pathway maps and display related many-genes-to-many-terms in a 2D view. 
Table 2. Sequences of primers used for qPCRs

\begin{tabular}{|c|c|c|}
\hline \multicolumn{2}{|l|}{ Genes } & Primer sequence $\left(5^{\prime}-3^{\prime}\right)$ \\
\hline \multirow[t]{2}{*}{ CASP1 (caspase 1) } & $\mathrm{F}$ a) & GAGCAGCCAGATGGTAGAGC \\
\hline & $\mathrm{R}$ b) & TTCACTTCCTGCCCACAGAC \\
\hline \multirow{2}{*}{$\begin{array}{l}\text { PYCARD (PYD and CARD } \\
\text { domain containing }\end{array}$} & $\mathrm{F}$ & ATCCAGGCCССТCСТCAG \\
\hline & $\mathrm{R}$ & GGTACTGCTCATCCGTCAGG \\
\hline \multirow[t]{2}{*}{ IL1B (interleukin 1 beta) } & $\mathrm{F}$ & TGAGCTCGCCAGTGAAATGA \\
\hline & $\mathrm{R}$ & AGATTCGTAGCTGGATGCCG \\
\hline \multirow[t]{2}{*}{ IL18 (interleukin 18) } & $\mathrm{F}$ & TGCAGTCTACACAGCTTCGG \\
\hline & $\mathrm{R}$ & ACTGGTTCAGCAGCCATCTT \\
\hline \multirow[t]{2}{*}{ IFNG (interferon gamma) } & $\mathrm{F}$ & TGAATGTCCAACGCAAAGCA \\
\hline & $\mathrm{R}$ & CTGGGATGCTCTTCGACCTC \\
\hline \multirow[t]{2}{*}{ IL33 (interleukin 33) } & $\mathrm{F}$ & TTATGAAGCTCCGCTCTGGC \\
\hline & $\mathrm{R}$ & CTGTTGACAGGCAGCGAGTA \\
\hline \multirow{2}{*}{$\begin{array}{l}\text { FGF1 (fibroblast growth factor } \\
\text { 1) }\end{array}$} & $\mathrm{F}$ & GGGGTTGCTTAGAGCTGTGT \\
\hline & $\mathrm{R}$ & GGAGCCAAGAATGTCAGCCT \\
\hline \multirow{2}{*}{$\begin{array}{l}\text { FGF2 (fibroblast growth factor } \\
\text { 2) }\end{array}$} & $\mathrm{F}$ & TCCACCTATAATTGGTCAAAGTGGT \\
\hline & $\mathrm{R}$ & CATCAGTTACCAGCTCСССС \\
\hline \multirow{2}{*}{$\begin{array}{l}\text { VEGFA (vascular endothelial } \\
\text { growth factor A) }\end{array}$} & $\mathrm{F}$ & CTGTCTAATGCCCTGGAGCC \\
\hline & $\mathrm{R}$ & ACGCGAGTCTGTGTTTTTGC \\
\hline \multirow[t]{2}{*}{ ANG (angiogenin) } & $\mathrm{F}$ & TCCCGTTGAAGGGAAACTGC \\
\hline & $\mathrm{R}$ & CCAGCACGAAGACCAACAAC \\
\hline \multirow{2}{*}{$\begin{array}{l}\text { PDGFA (platelet derived } \\
\text { growth factor subunit A) }\end{array}$} & $\mathrm{F}$ & GGGAACGCACCGAGGAAG \\
\hline & $\mathrm{R}$ & GGAGGAGAAACAGGGAGTGC \\
\hline \multirow{2}{*}{$\begin{array}{l}\text { PDGFB (platelet derived } \\
\text { growth factor subunit B) }\end{array}$} & $\mathrm{F}$ & GCTGAAAGGGTGGCAACTTC \\
\hline & $\mathrm{R}$ & GGGAATGAAAAATGGGCGCT \\
\hline \multicolumn{3}{|l|}{ Internal control } \\
\hline \multirow{2}{*}{$\begin{array}{l}\text { GAPDH } \\
\text { (glyceraldehyde-3-phosphate } \\
\text { dehydrogenase) }\end{array}$} & $\mathrm{F}$ & GAAAGCCTGCCGGTGACTAA \\
\hline & $\mathrm{R}$ & AGGAAAAGCATCACCCGGAG \\
\hline a) $\mathrm{F}$, sequence from sense stran & 15,0 & $R$, sequence from anti-sense strands \\
\hline
\end{tabular}

\section{Statistical analysis}

All data, expressed as the means \pm SD, were compared by one-way analysis of variance (ANOVA) using the Statistical Package of Social Science (SPSS, version $14.0 \mathrm{~K})$ program. Group means were considered significantly different at $p<0.05$, as determined by the technique of protected least-significant difference (LSD) when ANOVA indicated an overall significant treatment effect $(p<0.05)$.

\section{Results}

\section{Surface protein expression of human adipose-derived SVFs by passage}

SVFs were obtained from each of 3 male and female donors (Table 1) to observe gender differences in human adipose tissue-derived SVFs and were cultured until passage 3 to obtain sufficient numbers for co-culturing with HUVECs. First, we investigated differences in surface protein expression by SVFs according to passage number using flow cytometry, whereupon no differences were observed between the three passages (Fig. 1A).

\section{Determination of the $\mathrm{H}_{2} \mathrm{O}_{2}$ concentration and treatment time in HUVECs}

To determine the treatment duration and titration of $\mathrm{H}_{2} \mathrm{O}_{2}$ in HUVECs, cell viability and ROS generation in HUVECs were measured using Ez-Cytox and DCF-DA at different $\mathrm{H}_{2} \mathrm{O}_{2}$ concentrations $(0,10,20,30,40$, or $50 \mu \mathrm{M})$ and treatment times $(0,2,4$, or $6 \mathrm{hrs})$. HUVECs were most affected by ROS generation when treated with $40 \mu \mathrm{M}$ $\mathrm{H}_{2} \mathrm{O}_{2}$ for 4 hrs (Fig. 1B), although the cell viability was $87 \%$ at this concentration and treatment time (Fig. 1C). Therefore, HUVECs were treated with $40 \mu \mathrm{M}$ of $\mathrm{H}_{2} \mathrm{O}_{2}$ for $4 \mathrm{hrs}$ before being co-cultured with SVFs.

\section{Changes in transcripts related to inflammation and angiogenesis in HUVECs by SVFs}

HUVECs pre-treated with $\mathrm{H}_{2} \mathrm{O}_{2}$ were cultivated with isolated human adipose derived-SVFs from both male and female donors for $24 \mathrm{hrs}$. The expression levels of genes related to inflammation and angiogenesis in HUVECs were compared between the two groups using qPCR. Most of the inflammation-related genes (CASP1, PYCARD, IL1B, IL18, and IFNG) were significantly increased in HUVECs by $\mathrm{H}_{2} \mathrm{O}_{2}$ but were decreased in HUVECs co-cultured with SVFs (Fig. 2A). In addition, all genes associated with angiogenesis (FGF1, FGF2, VEGFA, ANG, PDGFA, and PDGFB) were remarkably down-regulated in HUVECs treated with $\mathrm{H}_{2} \mathrm{O}_{2}$ but were up-regulated in HUVECs co-cultured with SVFs (Fig. 2B). Interestingly, a significant difference between male and female donors was observed in only the gene expression of IL-33 and PDGFs (Fig. 2).

\section{Changes in proteins related to inflammation and angiogenesis in HUVECs by SVFs}

$\mathrm{H}_{2} \mathrm{O}_{2}$-treated HUVECs were co-cultured with SVF for $48 \mathrm{hrs}$, and the protein expression levels of anti-oxidant proteins (peroxiredoxin (PRX) and thioredoxin (TRX)), inflammatory factors (caspase-1, interleukin (IL)-1B, and IL-33), and angiogenic factors (VEGF, fibroblast growth factor (FGF)-2, and platelet-derived growth factor (PDGF)-2) were then determined by western blotting. Consequently, PRX and TRX levels were down-regulated by $\mathrm{H}_{2} \mathrm{O}_{2}$ but showed an upward trend in HUVECs co-cultured with SVFs in both groups (Fig. 3). Meanwhile, caspase-1 and IL-1B were significantly increased IL-33, VEGF, FGF-2, and PDGF-2 were remarkably decreased by $\mathrm{H}_{2} \mathrm{O}_{2}$, whereas these factors showed opposite expression patterns when co-cultivated with SVFs compared with $\mathrm{H}_{2} \mathrm{O}_{2}$ treatment alone (Fig. 3). However, few differences were found in the expression of proteins related to inflammation and angiogenesis between males and females, in contrast to the gene expression results (Fig. 3). 
A
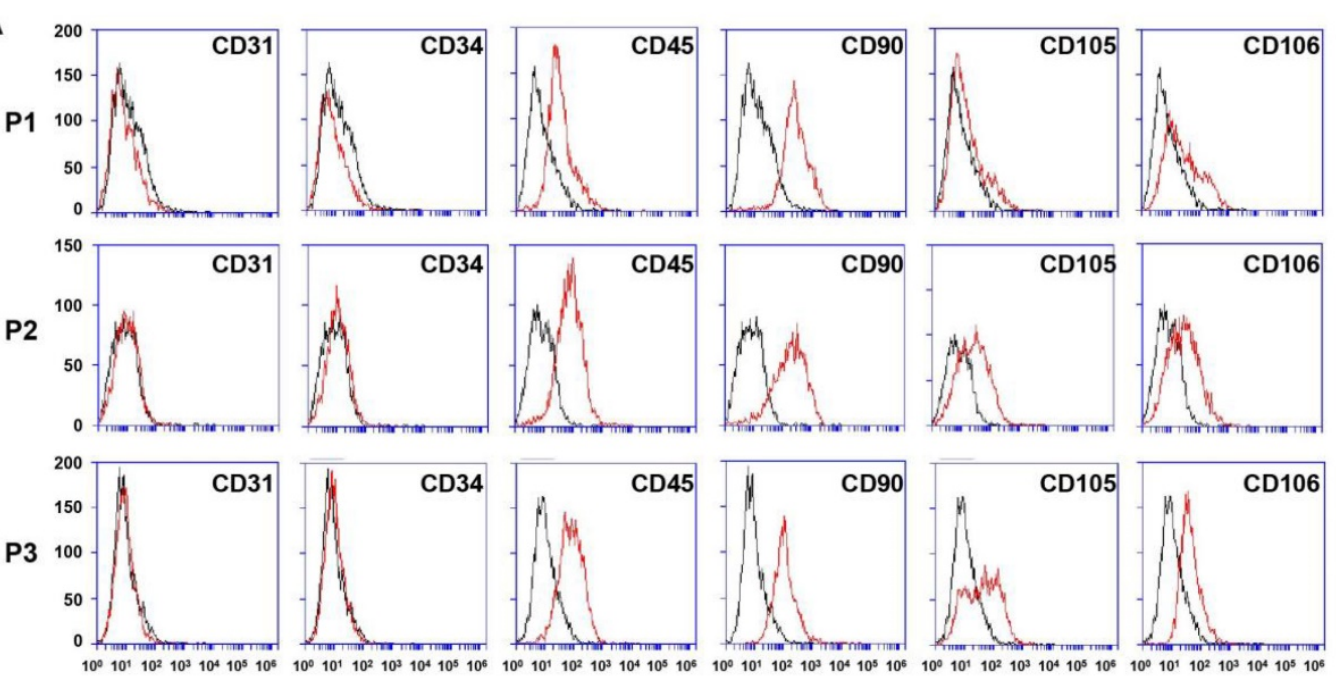

\section{Log Intensity}

B

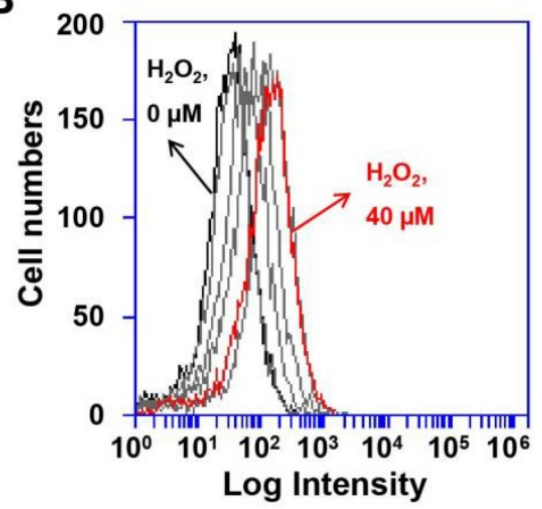

C

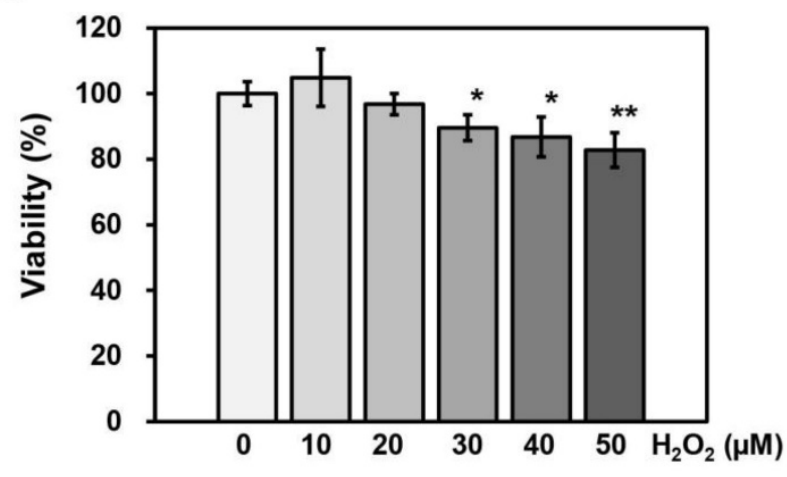

Figure 1. Surface protein expression on adipose-derived SVFs according to passage, as measured by (A) flow cytometry. (B) ROS generation and (C) Cell viability of HUVECs treated with different concentrations of $\mathrm{H}_{2} \mathbf{O}_{2}$ for $\mathbf{4}$ hrs. Information of SVF for characterization was summarized in Table 1 . P, passage. Cell viability and ROS generation were measured using Ez-Cytox and DCF-DA, respectively. Data are representative of three independent experiments. Significant differences between the non-treated $(0 \mu \mathrm{M})$ and $\mathrm{H}_{2} \mathrm{O}_{2}$-treated $(10,20,30,40$ or $50 \mu \mathrm{M})$ groups were determined using ANOVA, with $p$ values indicated as $* p<0.05$ and $* * p<0.01$.

A
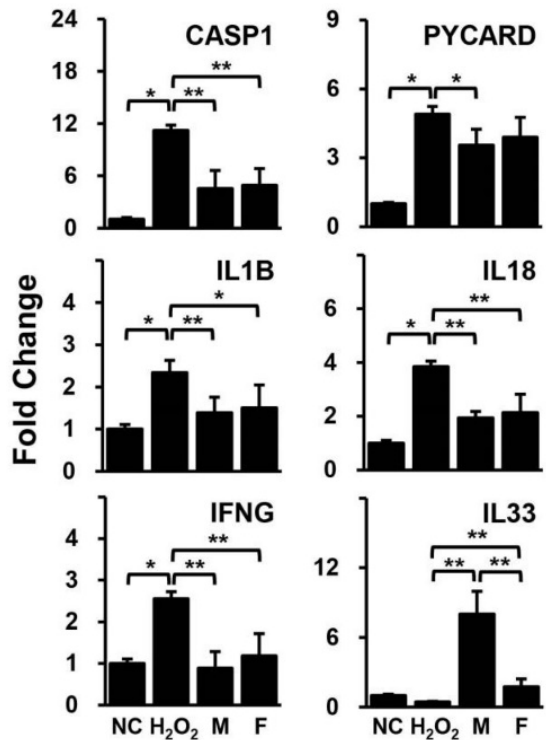

\section{B}
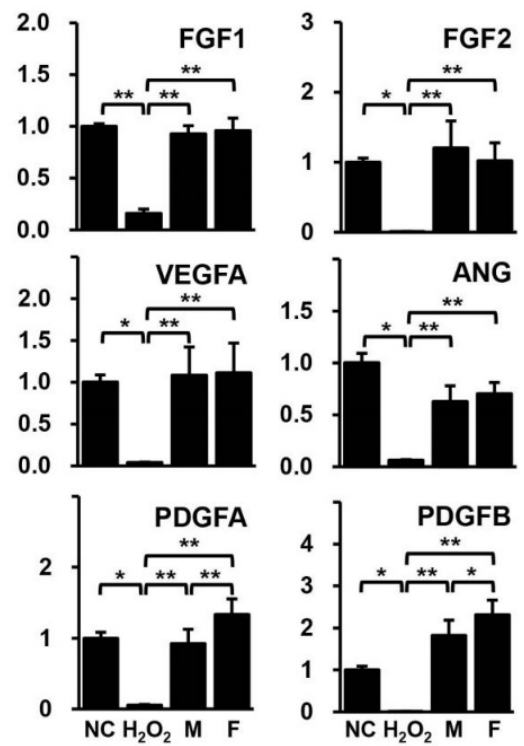

Figure 2. Gene expression related to (A) inflammation and (B) angiogenesis in HUVECs co-cultured with SVF, as determined by qPCR. Data are representative of three independent experiments. Details of the groups were provided in the Materials and Methods. Significant differences between groups were determined using ANOVA, with $p$ values indicated as $* p<0.05$ and $* * p<0.01$. 
A

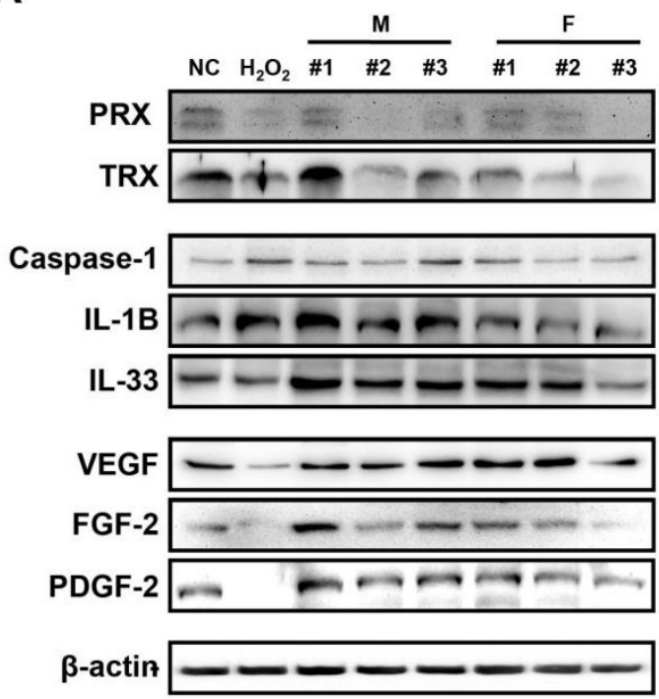

B

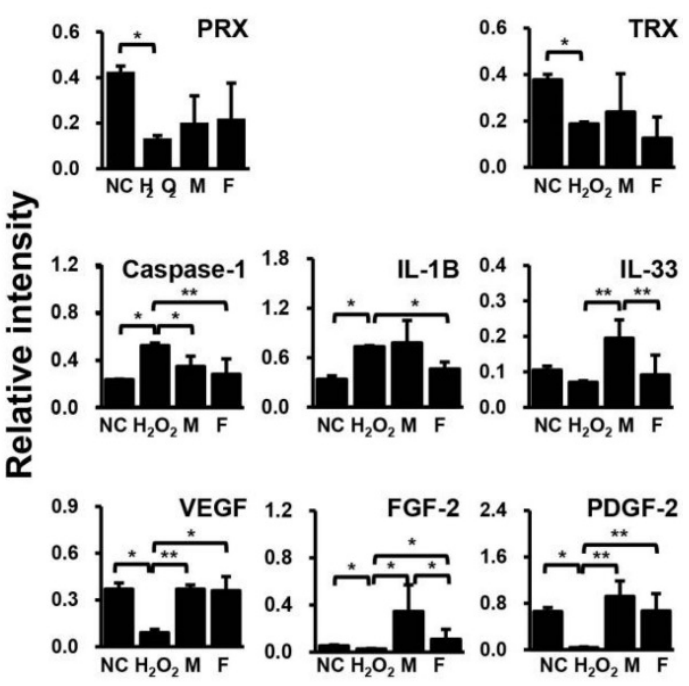

Figure 3. Differential regulation of proteins related to inflammation and angiogenesis in HUVECs in response to SVF and $\mathrm{H}_{2} \mathrm{O}_{2}$ treatment, as determined via immunoblotting. (A) Band intensity was measured as area density and analyzed in Image J. (B) Relative intensity levels indicate protein values normalized to $\beta$-actin levels. Data are representative of three independent experiments. Details of the groups were provided in the Materials and Methods. Significant differences between groups were determined using ANOVA, with $p$ values indicated as $* p<0.05$ and $* * p<0.01$.

Table 3. DAVID functional annotation clustering of differentially altered genes/proteins related to inflammation and angiogenesis in HUVECs by SVFs

\begin{tabular}{|c|c|c|c|c|c|}
\hline $\begin{array}{l}\text { Annotation } \\
\text { cluster }\end{array}$ & Enrichment Score: 3.06 & Count & $\begin{array}{l}\mathbf{P} \\
\text { Value }\end{array}$ & Benjamini & FDR \\
\hline $\begin{array}{l}\text { KEGG } \\
\text { PATHWAY }\end{array}$ & $\begin{array}{l}\text { Cytosolic DNA-sensing } \\
\text { pathway }\end{array}$ & 5 & $1.3 \mathrm{E}-6$ & $8.5 \mathrm{E}-5$ & $1.4 \mathrm{E}-3$ \\
\hline $\begin{array}{l}\text { KEGG }_{-} \\
\text {PATHWAY }\end{array}$ & Influenza A & 6 & 2.2E-6 & $6.9 \mathrm{E}-5$ & $2.2 \mathrm{E}-3$ \\
\hline $\begin{array}{l}\text { KEGG_- } \\
\text { PATHWAY }\end{array}$ & Salmonella infection & 5 & $3.8 \mathrm{E}-6$ & $8.1 \mathrm{E}-5$ & 3.9E-3 \\
\hline $\begin{array}{l}\text { GOTERM_- } \\
\text { BP_DIRECT }\end{array}$ & Interleukin & 3 & $5.8 \mathrm{E}-6$ & $4.1 \mathrm{E}-4$ & $8.4 \mathrm{E}-3$ \\
\hline $\begin{array}{l}\text { KEGG_- }_{-} \\
\text {PATHWAY }\end{array}$ & Legionellosis & 4 & $5.2 \mathrm{E}-5$ & $6.6 \mathrm{E}-4$ & $5.3 \mathrm{E}-2$ \\
\hline $\begin{array}{l}\text { KEGG_- } \\
\text { PATHWAY }\end{array}$ & $\begin{array}{l}\text { NOD-like receptor } \\
\text { signaling pathway }\end{array}$ & 4 & $5.2 \mathrm{E}-5$ & $5.8 \mathrm{E}-4$ & $5.6 \mathrm{E}-2$ \\
\hline $\begin{array}{l}\text { GOTERM_- } \\
\text { BP_DIRECT }\end{array}$ & $\begin{array}{l}\text { Positive regulation of } \\
\text { interleukin- } 1 \text { beta secretion }\end{array}$ & 3 & $9.8 \mathrm{E}-5$ & $2.4 \mathrm{E}-3$ & $1.4 \mathrm{E}-1$ \\
\hline BIOCARTA & IL-18 signaling pathway & 3 & $3.2 \mathrm{E}-4$ & $9.1 \mathrm{E}-3$ & 2.7E-1 \\
\hline $\begin{array}{l}\text { GOTERM_- } \\
\text { BP_DIRECT }\end{array}$ & $\begin{array}{l}\text { Positive regulation of } \\
\text { interferon-gamma } \\
\text { production }\end{array}$ & 3 & 4.3E-4 & $8.8 \mathrm{E}-3$ & $6.2 \mathrm{E}-1$ \\
\hline $\begin{array}{l}\text { GOTERM_- } \\
\text { BP_DIRECT }\end{array}$ & $\begin{array}{l}\text { Positive regulation of } \\
\text { interleukin- } 6 \text { production }\end{array}$ & 3 & $4.9 \mathrm{E}-4$ & $9.5 \mathrm{E}-3$ & 7.0E-1 \\
\hline $\begin{array}{l}\text { KEGG_- } \\
\text { PATHWAY }\end{array}$ & Pertussis & 3 & $4.9 \mathrm{E}-3$ & 1.7E-2 & 4.9E0 \\
\hline $\begin{array}{l}\text { GOTERM_- } \\
\text { BP_DIRECT }\end{array}$ & Signal transduction & 5 & $5.1 \mathrm{E}-3$ & 6.7E-2 & 7.1E0 \\
\hline $\begin{array}{l}\text { GOTERM_- } \\
\text { BP_DIRECT }\end{array}$ & Apoptotic process & 4 & $5.2 \mathrm{E}-3$ & $6.6 \mathrm{E}-2$ & $7.2 \mathrm{E} 0$ \\
\hline $\begin{array}{l}\text { GOTERM_- } \\
\text { BP_DIRECT }\end{array}$ & Inflammatory response & 3 & $2.5 \mathrm{E}-2$ & 2.6E-1 & 3.0E1 \\
\hline $\begin{array}{l}\text { GOTERM_- } \\
\text { CC_DIRECT }\end{array}$ & Cytosol & 5 & 1.3E-1 & 6.1E-1 & 7.3E1 \\
\hline $\begin{array}{l}\text { UP_SEQ_ } \\
\text { FEATURE }\end{array}$ & Splice variant & 6 & 4.3E-1 & $1.0 \mathrm{E} 0$ & $9.9 \mathrm{E} 1$ \\
\hline $\begin{array}{l}\mathrm{UP}_{-} \\
\text {KEYWORDS }\end{array}$ & Cytoplasm & 4 & 4.9E-1 & $9.2 \mathrm{E}-1$ & $1.0 \mathrm{E} 2$ \\
\hline $\begin{array}{l}\text { UP_- } \\
\text { KEYWORDS }\end{array}$ & Phosphoprotein & 4 & 8.8E-1 & $1.0 \mathrm{E} 0$ & $1.0 \mathrm{E} 2$ \\
\hline
\end{tabular}

\section{Network prediction of HUVEC targets related to inflammation and angiogenesis after exposure to SVFs}

To determine differentially altered genes/proteins in HUVECs related to inflammation and angiogenesis after exposure to SVFs, we classified genes/proteins based on the bioinformatics resources of DAVID. After entering a list of genes into DAVID, among multiple KEGG pathways, the pathways in HUVECs that were most affected by SVFs were related to cytosolic DNA-sensing (Table 3 and Fig. 4). Five (PYCARD, CASP1, IL-1B, IL-18, and IL-33) genes were mainly localized to the cytosolic DNA-sensing pathway, and the activation of CASP1 can also result in a rapid inflammatory form of cell death called pyroptosis. These results suggested that adiposederived SVFs ameliorated oxidative stress-induced pyroptosis/apoptosis.

\section{Discussion}

Adipose-derived SVFs exhibit mesodermal and ectodermal capacity and contain heterogeneous cell populations such as blood-derived cells $\left(\mathrm{CD} 45^{+}\right)$, ASCs (CD31-, CD34+, CD45-, CD90 ${ }^{+}, \mathrm{CD}^{-} 105^{-}$and CD106 ${ }^{+}$, MSCs (CD31-, CD34-, CD45-, CD90+, CD105+ and $\left.\mathrm{CD}^{+} 6^{+}\right)$, endothelial (progenitor) cells $\left(\mathrm{CD} 31^{+}\right.$, $\mathrm{CD}_{4}{ }^{+}, \mathrm{CD}_{45}{ }^{-}, \mathrm{CD}^{+}{ }^{+}, \mathrm{CD} 105^{-}$and $\left.\mathrm{CD}^{-} 6^{+}\right)$, vascular smooth muscle cells (CD31-, CD34+, CD45-, CD90 ${ }^{+}$, CD105- and CD106-), pericytes (CD31-, CD34', CD45-, $\mathrm{CD}^{+}{ }^{+}, \mathrm{CD}^{-105^{-}}$and $\left.\mathrm{CD}^{-} 6^{+}\right)$, and other cells $[24,25]$. Minor differences between freshly isolated SVFs and cultured SVFs exist in terms of their phenotype and 
A

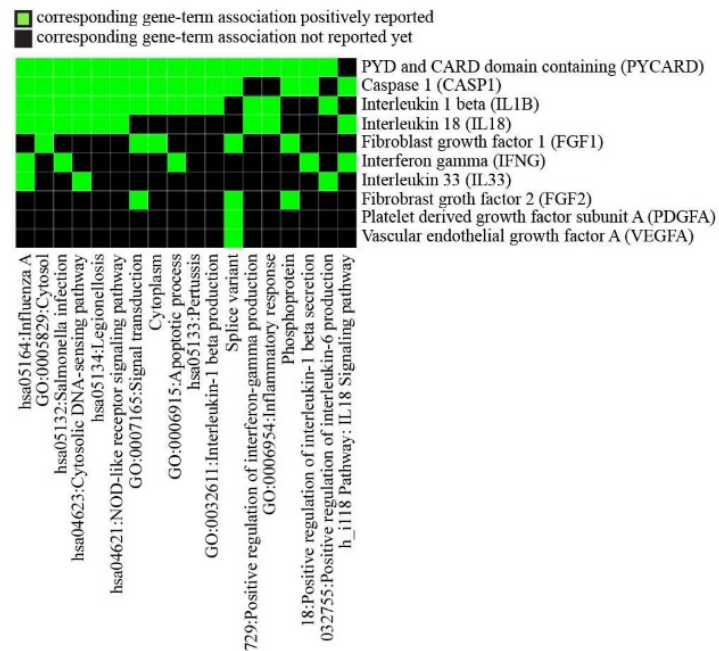

B

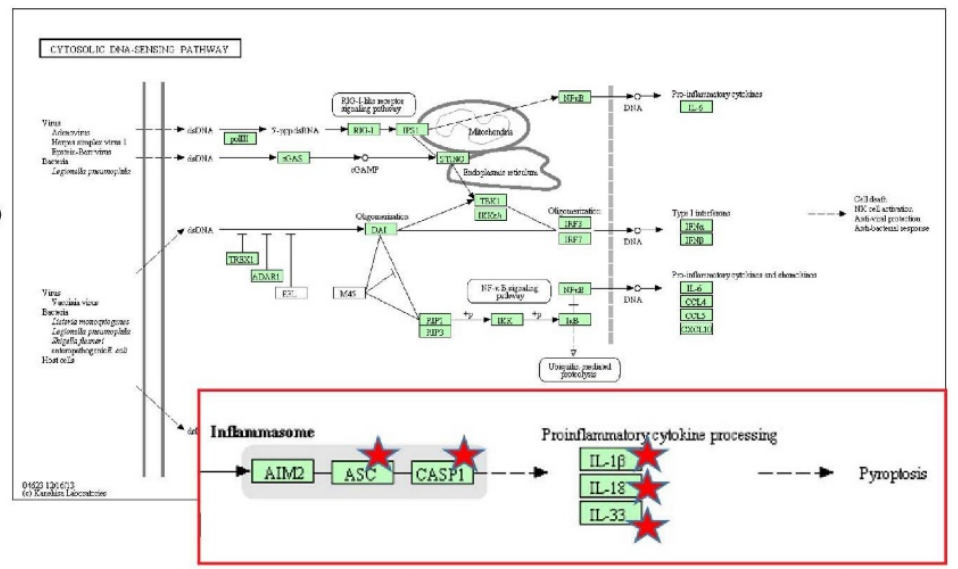

Figure 4. Discovery enriched functional-related genes/proteins related to inflammation and angiogenesis in $\mathrm{HUVEC}$ in response to $\mathrm{SVF}$ and $\mathrm{H}_{2} \mathrm{O}_{2}$ treatment. (A) 2D view of regulated genes by DAVID and (B) predicted pathway in KEGG pathway.

kinetics [26], but differences in the surface marker expression (CD31-, CD34-, CD45 ${ }^{+}, \mathrm{CD}^{-} 0^{+}, \mathrm{CD} 105^{+}$, and $\mathrm{CD} 106^{+}$) of cultured SVFs were negligible by passage 3 in the present study (Fig. 1A). These results suggest that these SVFs contain heterogeneous cell populations similar to freshly isolated SVFs. In the present study, we aimed to determine whether SVF transplantation shows differential effects according to gender in inflammatory and angiogenetic properties; thus, we investigated the differences in gene and protein expression related to inflammation and angiogenesis in HUVECs co-cultured with isolated adipose-derived SVFs from males and females by oxidative stress.

Redox signaling influences many physiological processes in the heart and plays critical roles in pathological cardiac remodeling [27]. ROS production triggers inflammation and/or regulates the inflammasome, which is common for heart disease and stroke patients and thought to be a sign of an atherogenic response [21]. The inflammasome is a multiprotein oligomer consisting of CASP1, PYCARD, NALP, which enhances the maturation of the inflammatory cytokines Interleukin $1 \beta$ (IL-1 $\beta$ ) and Interleukin 18 (IL-18) to induce IFN- $\gamma$ secretion [28] and cleavage and inactivation of IL-33 [29]. In addition, the inflammasome promotes angiogenesis, either directly or via the generation of active oxidation products, including peroxidized lipids [30], but $\mathrm{H}_{2} \mathrm{O}_{2}$ mediated by NADPH oxidase has biphasic effects on angiogenesis in vitro and in vivo [31]. Inflammation and angiogenesis have long been coupled in many chronic inflammatory disorders and have further been substantiated by the finding that several non-inflammatory disorders display both inflammation and angiogenesis in an exacerbated manner [32]. In addition, the interplay among inflammatory cells, endothelial cells and fibroblasts at sites of chronic inflammation can trigger inflammation and angiogenesis through the same molecular events, further strengthening this association [32]. Pro-inflammatory cytokines and chemokines induce the recruitment of immune cells [33], and these infiltrated inflammatory cells also synthesize pro-inflammatory cytokines, regulating both chronic inflammation and angiogenesis [34].

Many therapeutic studies have reported an initial decrease in inflammation and immune responses at the site of SVF injection [2, 6, 7, 35]. Moreover, SVFs promote angiogenesis, and neovascularization has major implications for diseases characterized by poor vascularization, ischemia, and necrosis [2]. The application of SVFs has successfully resulted in neovascular formation in acute myocardial infarction, burn wounds, diabetic foot ulcers and ischemic muscle [6,7]. With this connection, in our study, we also observed anti-inflammatory and pro-angiogenetic properties in HUVECs co-cultured with SVFs under oxidative stress conditions (Figs. 2 and 3). Furthermore, we observed that these properties of SVFs may partially differs according to gender because gender can be major factor in stem cell transplantation [9]. In fact, NACHT, LRR and PYD domains-containing protein 3 (NLRP3) and Interferon-inducible protein 2 (AIM2) inflammasomes exhibited gender-dependent differential activation in SLE macrophages [36] and atherosclerosis [37] because sex hormones alter the 
immune response, resulting in different disease phenotypes according to gender [37]. In addition, inflammatory cytokines and angiogenetic factors in MSCs also showed differential expression in male and female mice [19]. In the present study, dramatic differences were found in the gene expression of some inflammatory (IL-33) and angiogenetic factors (PDGFs) in HUVECs co-cultured with adipose-derived SVFs from male ( $\mathrm{M}$ group) and female ( $F$ group) donors under oxidative stress conditions. Inflammasomes can also promote pro-inflammatory or pro-death functions of CASP1. The activated CASP1 can trigger an inflammatory type of programmed cell death called pyroptosis [38]. In this study, we showed that oxidative stress could induce pyroptosis/apoptosis in HUVECs. Pyroptosis was inhibited by CASP1 inhibition in HUVECs co-cultured with adipose-derived SVFs from male and female donors, but it was more significantly altered by SVFs from female donors. Gene expression is often interpreted in terms of protein levels, but the correlation can be as little as $40 \%$ depending on the system [39]. Therefore, differences between gene and protein expression in our data were likely caused by various factors such as RNA stability and processing and protein stability and modification, since proteins may be affected by many processes between transcription and translation [39].

This study is the first to describe the inflammatory and angiogenetic factor expression profiles in HUVECs induced by isolated SVFs from donors of different genders under oxidative stress conditions. These results could provide the basis for the clinical application of SVF transplantation for patients with impaired tissues. However, further studies using more donors, together with various environmental conditions and varied target proteins, are required to better understand the influence of gender on human adipose-derived SVFs.

\section{Abbreviations}

ASCs, adipose-derived stem cells; HUVECs, human umbilical vein endothelial cells; MSCs, mesenchymal stem cells; ROS, reactive oxygen species; SVFs, stromal vascular fractions.

\section{Acknowledgements}

This study was supported by a Korea Science and Engineering Foundation grant funded by the Korean government (MEST) (NRF-2015M3A9E6029519).

\section{Authors' Contributions}

Soyeon Lim and Il-Kwon Kim contributed equally to this work. Sang Woo Kim and Ki-Chul
Hwang are corresponding authors.

\section{Competing Interests}

The authors declare that they have no conflicts of interest.

\section{References}

1. Nguyen A, Guo J, Banyard DA, Fadavi D, Toranto JD, Wirth GA, et al. Stromal vascular fraction: A regenerative reality? Part 1: Current concepts and review of the literature. Journal of Plastic, Reconstructive and Aesthetic Surgery. 2016; 69: $170-179$

2. Guo J, Nguyen A, Banyard DA, Fadavi D, Toranto JD, Wirth GA, et al. Stromal vascular fraction: A regenerative reality? Part 2: Mechanisms of regenerative action. Journal of Plastic, Reconstructive and Aesthetic Surgery. 2016; 69: 180-188.

3. Alt E, Pinkernell K, Scharlau M, Coleman M, Fotuhi P, Nabzdyk C, et al. Effect of freshly isolated autologous tissue resident stromal cells on cardiac function and perfusion following acute myocardial infarction. International Journal of Cardiology. 2010; 144: 26-35.

4. Leblanc AJ, Nguyen OT, Touroo JS, Aird AL, Chang RC, Ng CK, et al. Adipose-derived cell construct stabilizes heart function and increases microvascular perfusion in an established infarct. Stem Cells Translational Medicine. 2013; 2: 896-905.

5. Mazo M, Cemborain A, Gavira JJ, Abizanda G, Arana M, Casado M, et al. Adipose stromal vascular fraction improves cardiac function in chronic myocardial infarction through differentiation and paracrine activity. Cell Transplantation. 2012; 21: 1023-1037.

6. Premaratne GU, Ma LP, Fujita M, Lin X, Bollano E, Fu M. Stromal vascular fraction transplantation as an alternative therapy for ischemic heart failure: anti-inflammatory role. Journal of Cardiothoracic Surgery. 2011; 6: 43.

7. van Dijk A, Naaijkens BA, Jurgens WJ, Nalliah K, Sairras S, van der Pijl RJ, et al. Reduction of infarct size by intravenous injection of uncultured adipose derived stromal cells in a rat model is dependent on the time point of application. Stem Cell Research. 2011; 7: 219-229.

8. Han S, Sun HM, Hwang KC, Kim SW. Adipose-Derived Stromal Vascular Fraction Cells: Update on Clinical Utility and Efficacy. Criticle Reviews in Eukaryotic Gene Expression. 2015; 25: 145-152.

9. Siennicka K, Zolocinska A, Stepien K, Lubina-Dabrowska N, Maciagowska M, Zolocinska E, et al. Adipose-Derived Cells (Stromal Vascular Fraction) Transplanted for Orthopedical or Neurological Purposes: Are They Safe Enough? Stem Cells International. 2016; 2016: 5762916.

10. Harrison D, Griendling KK, Landmesser U, Hornig B, Drexler H. Role of oxidative stress in atherosclerosis. American Journal of Cardiology, 2003; 91: 7A-11A.

11. Cai H, Harrison DG. Endothelial dysfunction in cardiovascular diseases: the role of oxidant stress. Circulation Research. 2000; 87: 840-844.

12. White CR, Brock TA, Chang LY, Crapo J, Briscoe P, Ku D, et al. Superoxide and peroxynitrite in atherosclerosis. Proceedings of the National Academy of Sciences of the United States of America. 1994; 91: 1044-1048.

13. Kojda G, Harrison D. Interactions between $\mathrm{NO}$ and reactive oxygen species: pathophysiological importance in atherosclerosis, hypertension, diabetes and heart failure. Cardiovascular Research. 1999; 43: 562-571.

14. Condorelli G, Borello U, De Angelis L, Latronico M, Sirabella D, Coletta M, et al. Cardiomyocytes induce endothelial cells to trans-differentiate into cardiac muscle: implications for myocardium regeneration. Proceedings of the National Academy of Sciences of the United States of America. 2001; 98: 10733-10738.

15. Tajiri N, Duncan K, Borlongan MC, Pabon M, Acosta S, de la Pena I, et al. Adult stem cell transplantation: is gender a factor in stemness? International Journal of Molecular Sciences. 2014; 15: 15225-15243.

16. Yuan J, Yu JX, Ge J. Sexual dimorphism on the neurogenic potential of rhesus monkeys mesenchymal stem cells. Biochemical and Biophysical Research Communications. 2010; 396: 394-400.

17. Waldron J, McCourty A, Lecanu L. Aging differentially affects male and female neural stem cell neurogenic properties. Stem Cells Cloning. 2010; 3: 119-127.

18. Nakada D, Oguro H, Levi BP, Ryan N, Kitano A, Saitoh Y, et al. Oestrogen increases haematopoietic stem-cell self-renewal in females and during pregnancy. Nature. 2014; 505: 555-558

19. Crisostomo PR, Wang M, Herring CM, Markel TA, Meldrum KK, Lillemoe $\mathrm{KD}$, et al. Gender differences in injury induced mesenchymal stem cell apoptosis and VEGF, TNF, IL-6 expression: role of the $55 \mathrm{kDa}$ TNF receptor (TNFR1). Journal of Molecular and Cellular Cardiology. 2007; 42: 142-149.

20. Tirziu D, Giordano FJ, Simons M. Cell communications in the heart. Circulation. 2010; 122: 928-937.

21. Burgoyne JR, Mongue-Din H, Eaton P, Shah AM. Redox signaling in cardiac physiology and pathology. Circulation Research. 2012; 111: 1091-1106.

22. Choi JW, Kim KE, Lee $\mathrm{CY}$, Lee J, Seo $\mathrm{HH}$, Lim $\mathrm{KH}$, et al. Alterations in cardiomyocyte differentiation-related proteins in rat mesenchymal stem cells exposed to hypoxia. Cellular Physiology and Biochemistry. 2016; 39: 1595-1607. 
23. Huang da W, Sherman BT, Lempicki RA. Systematic and integrative analysis of large gene lists using DAVID bioinformatics resources. Nature Protocols. 2009; 4: 44-57.

24. Lin K, Matsubara Y, Masuda Y, Togashi K, Ohno T, Tamura T, et al. Characterization of adipose tissue-derived cells isolated with the Celution system. Cytotherapy. 2008; 10: 417-426.

25. Zuk PA, Zhu M, Ashijan P, De Ugarte DA, Huang JI, Mizuno H, et al. Human adipose tissue is a source of multipotent stem cells. Molecular Bioloby of the Cell. 2002; 13: 4279-4295.

26. Varma MJ, Breuls RG, Schouten TE, Jurgens WJ, Bontkes HJ, Schuurhuis GJ, et al. Phenotypical and functional characterization of freshly isolated adipose tissue-derived stem cells. Stem Cells and Development. 2007; 16: 91-104.

27. Martinon F, Burns K, Tschopp J. The inflammasome: a molecular platform triggering activation of inflammatory caspases and processing of proIL-beta. Molecular Cell. 2002; 10: 417-426.

28. Gu Y, Kuida K, Tsutsui H, Ku G, Hsiao K, Fleming MA, et al. Activation of interferon-gamma inducing factor mediated by interleukin-1beta converting enzyme. Science. 1997; 275: 206-209.

29. Cayrol C, Girard JP. The IL-1-like cytokine IL-33 is inactivated after maturation by caspase- 1 . Proceedings of the National Academy of Sciences of the United States of America. 2009; 106: 9021-9026.

30. Pashkow FJ. Oxidative stress and inflammation in heart disease: Do antioxidants have a role in treatment and/or prevention? International Journal of Inflammation. 2011; 2011: 514623.

31. Mu P, Liu Q, Zheng R. Biphasic regulation of $\mathrm{H} 2 \mathrm{O} 2$ on angiogenesis implicated NADPH oxidase. Cell Biology International. 2010; 34: 1013-1020.

32. Costa C, Incio J, Soares R. Angiogenesis and chronic inflammation: cause or consequence? Angiogenesis. 2007; 10: 149-166.

33. Smolen JS, Redlich K, Zwerina J, Aletaha D, Steiner G, Schett G. Pro-inflammatory cytokines in rheumatoid arthritis: pathogenetic and therapeutic aspects. Clinical Reviews in Allergy and Immunology. 2005; 28: 239-248.

34. Monaco C, Andreakos E, Kiriakidis S, Feldmann M., Paleolog E. T-cell-mediated signalling in immune, inflammatory and angiogenic processes: the cascade of events leading to inflammatory diseases. Current Drug Targets-Inflammation and Allergy. 2004; 3: 35-42.

35. Fu S, Luan J, Xin M, Wang Q, Xiao R, Gao Y. Fate of adipose-derived stromal vascular fraction cells after co-implantation with fat grafts: evidence of cell survival and differentiation in ischemic adipose tissue. Plastic and Reconstructive Surgery. 2013; 132: 363-373.

36. Yang CA, Huang ST, Chiang BL. Sex-dependent differential activation of NLRP3 and AIM2 inflammasomes in SLE macrophages. Rheumatology (Oxford). 2015; 54: 324-331.

37. Fairweather D. Sex differences in inflammation during atherosclerosis. Clinical Medicine Insights Cardiology. 2014; 8: 49-59.

38. Tait SW, Ichim G, Green DR. Die another way--non-apoptotic mechanisms of cell death. Journal of Cell Science. 2014; 127: 2135-2144.

39. Vogel C, Marcotte EM. Insights into the regulation of protein abundance from proteomic and transcriptomic analyses. Nature Reviews Genetics. 2012; 13: 227-232. 